\title{
Factors related to quilombola attendance to child follow-up appointments
}

\author{
Fatores relacionados à assiduidade de quilombolas às consultas de acompanhamento infantil \\ Los factores asociados a la asiduidad de quilombolas en consultas de seguimiento infantil
}

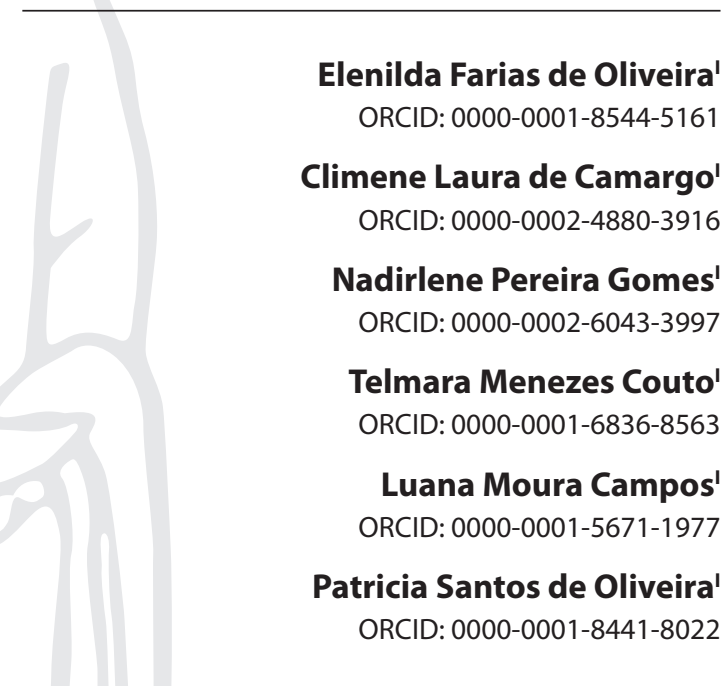

' Universidade Federal da Bahia. Salvador, Bahia, Brazil.

How to cite this article:

Oliveira EF, Camargo CL, Gomes NP, Couto TM

Campos LM, Oliveira PS. Factors related to quilombola attendance to child follow-up appointments.

Rev Bras Enferm. 2019;72(Suppl 3):9-16.

doi: http://dx.doi.org/10.1590/0034-7167-2017-0605

Corresponding Author:

Elenilda Farias de Oliveira

E-mail: didafarias@yahoo.com.br

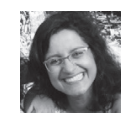

Submission: 10-01-2017 Approval: 04-13-2018

\begin{abstract}
Objective: To understand factors interfering with the attendance of quilombola children to growth and development follow-up appointments. Method: It is a qualitative research based on Symbolic interactionism, during which 14 mothers of children bellow 1 year-old were interviewed, who attended to the Family Health Unit at Ilha de Maré, Bahia, Brazil. Results: Appointment attendance is affected by factors intrinsic to mothers (meaning of child health follow-up; association between appointments and children falling ill; personal issues) and extrinsic factors, related to the service (availability, long waiting time for appointments and its quality). Final considerations: An administration prioritizing the service's organization is required, which can prioritize attendances and the reduction of waiting time, specially given the personal issues that compromise going to the unit.

Descriptors: Growth and Development; Child Care; Nursing in Community Health; Public Health; Interpersonal Relations.
\end{abstract}

\section{RESUMO}

Objetivo: Apreender fatores que interferem na assiduidade de crianças quilombolas às consultas de acompanhamento do crescimento e desenvolvimento. Método: Pesquisa qualitativa ancorada no Interacionismo Simbólico, durante a qual foram entrevistadas 14 mães de crianças menores de um ano e que frequentavam a Unidade de Saúde da Família de Ilha de Maré, Bahia, Brasil. Resultados: A assiduidade às consultas sofre influência de fatores intrínsecos às mães (significado do acompanhamento à saúde infantil; vinculação das consultas ao adoecimento da criança; questões pessoais) e fatores extrínsecos relativos ao serviço (disponibilidade de agendamento, amplo tempo de espera para as consultas e qualidade das mesmas). Considerações Finais: Urge uma gestão que priorize a reorganização do serviço, com prioridade aos agendamentos e o aprimoramento profissional, tendo em vista a melhoria da qualidade do atendimento e a redução do tempo de espera, principalmente considerando as questões pessoais que comprometem a ida à unidade.

Descritores: Crescimento e Desenvolvimento; Cuidado da Criança; Enfermagem em Saúde Comunitária; Saúde Pública; Relações Interpessoais.

\section{RESUMEN}

Objetivo: Identificar los factores que interfieren en la asiduidad de niños quilombolas en las consultas de seguimiento para el crecimiento y desarrollo. Método: Investigación cualitativa con base en el Interaccionismo Simbólico, en la cual se entrevistó 14 madres de niños menores de un año de edad y que frecuentaban la Unidad de Salud de la Familia de llha de Maré, Bahia, Brasil. Resultados: La asiduidad en las consultas sufre influencia de factores intrínsecos a las madres -significado de seguimiento para la salud infantil, asociación de las consultas con la enfermedad del niño; cuestiones personales- y de factores extrínsecos relativos al servicio -disponibilidad de agenda, mucho tiempo de espera para las consultas y su calidad-. Consideraciones Finales: Es necesario haber una gestión que priorice la reorganización del servicio, con mayor prioridad a las agendas y al perfeccionamiento profesional, teniendo en cuenta la mejora de la calidad de la atención médica prestada y la reducción del tiempo de espera, principalmente considerando las cuestiones personales que les comprometen venir a la unidad.

Descriptores: Crecimiento y Desarrollo; Cuidado del Niño; Enfermería en Salud Comunitaria; Salud Pública; Relaciones Interpersonales. 


\section{INTRODUCTION}

The bigger vulnerability of quilombola children for falling ill requires political strategies that guarantee this population's quality of life, among these strategies are the growth and development follow-up appointments (GDF). Which, since they favor the bonds between mother and professional, may represent an important space for strengthening family attendance to appointments.

Researches highlight the exposition of children to different vulnerability situations, which involve from physiologic aspects, such as immunological immaturity, as well as external events, as the restricted access to education, garbage collection, basic sanitation, and piped water ${ }^{(1-2)}$. Such reality is not restricted to Brazil. It is highlighted, for example, in Ireland, which has mortality rates four times bigger for children living in poverty ${ }^{(3)}$, and also in countries such as China, Burma/Myanmar ${ }^{(4)}$ and in the Sub-Saharan Africa ${ }^{(5)}$. The situation tends to be worsened when dealing with black children, specially the ones coming from quilombola communities, a fact that may be related to the worst life and health conditions, to the lower life expectancy at birth, and to the greater difficulty in accessing health services ${ }^{(5-6)}$.

Within this context GDF appointments are set as a vigilance strategy for child health care ${ }^{(7)}$. Such strategy is inserted in the Brazilian National Basic Care Policy ${ }^{(8)}$, constituting the GDF Program, being stablished in the Law no. 13,257 of March $8^{\text {th }}, 2016$, which sets the public policies for early childhood and has health as a priority area ${ }^{(9)}$.

GDF appointments, originally known as childcare, occur systematically and in a planned manner, through the supervision and guidance of vaccination, breast feeding and hygiene; promotion of healthy habits, besides the prevention of accidents and grievances, as well as their early identification. The appointments also allow for trust, respect, and the strengthening of bonds between the health professional and the family, a factor that favors the continuity of looking for the services, as well as family autonomy and strengthening towards health care ${ }^{(10-11)}$.

Considering that stablishing bonds between the user and the professional has been mentioned due to its efficacy in health actions, an aspect that directly affects child care ${ }^{(10-11)}$, scientific evidences sign the relevance of GDF appointments. A Brazilian systematic review research has shown the importance of these appointments for the reduction of children mortality risks ${ }^{(12)}$. It is possible to conclude, thus, that, since the implementation of GDF appointments, in 1984, a process of improving health conditions for Brazilian children has begun - which can be perceived by the reduction of mortality rates between the years 1990 and 2013, which had reached $78 \%{ }^{(13)}$.

While some investigations indicate a relation between the reduction of child morbimortality percentages and GDF appointments, others draw the attention for the child unattendance to these spaces. A study carried out in an attendance sector of the São Leopoldo maternity, Rio Grande do Sul, Brazil, has demonstrated that, from the 393 children born in public hospitals, 53.2\% did not attend regularly to childcare appointments ${ }^{(14)}$. In a population base study carried out in 2013 with 1,711 children aging from zero to five years old, in Maranhão, Brazil, it was verified that GDF appointments in the first year of life happened for $38.4 \%$ of infants ${ }^{(15)}$. Another study performed in Sobral, Ceará, Brazil, also corroborates to the situation of unattendance to GDF appointments for many reasons ${ }^{(16)}$.
Considering that these scientific evidences point out the non-adhesion to appointments as a problem for the population in general, it is highlighted the lack of knowledge regarding this reality in quilombola communities. It is important to also emphasize that, despite the improvements in the Brazilian child morbimortality framework, this fact does not portray the reality for black children. Data from the United Nations Children's Fund (UNICEF) draws the attention for the fact that, in Brazil, mortality among black children is around $40 \%$ bigger than for white children ${ }^{(17)}$. Along with that, in the Sub-Saharan Africa, where the population is mostly black, the probability of a child dying before five yearsold increases to 1 for each 12 births, while in the United States, this probability is of 1 for each 140 live births ${ }^{(2)}$. Given the context of higher exposition of black children to illnesses and death, it is relevant to highlight that it is crucial to perform actions, in the collective health scope, for health promotion and illness prevention based on efficient behaviors that are able to overcome the vulnerability situations of the quilombola population ${ }^{(6)}$.

Considering that the systematic follow-up of quilombola children to GDF appointments will reflect on the improvement of health conditions for this population, and that the bond between mothers and health professionals is essential for this process, we ask: for quilombola mothers, which factors affect the children's attendance to GDF appointments?

\section{OBJECTIVE}

To understand the factors interfering with the attendance of quilombola children to growth and development follow-up classes.

\section{METHOD}

\section{Ethical aspects}

This research was submitted and approved by the Committee of Research Ethics of the Nursing School of the Universidade Federal da Bahia, under the statement no. 1.023.744, CAEE 39922214.5.0000.5531. An informed consent form was designed, in which the criteria stablished in the Resolution 466, of December $12^{\text {th }}, 2010$, of the National Health Council, were respected.

\section{Theoretical-methodological references and type of study}

It is a descriptive research with qualitative approach, which was based on the Symbolic Interactionism (SI) theory. This theory has been employed in nursing researches since it adopts, as its main concept, the meaning of action in the individual and collective scope, based on the interaction among social actors ${ }^{(18)}$. This study is related to the thesis intitled "The Growth and Development Follow-up Appointment for Quilombola Children", in light of the Symbolic Interactionism (SI).

\section{Methodological Procedures}

\section{Study scenario}

The study was carried out in five quilombola communities located in the llha de Maré, Praia Grande, Bananeira, Martelo, 
Ponta Grossa, and Porto dos Cavalos, with a total population of 4,236 inhabitants, registered in the 2010 Demographic Census ${ }^{(19)}$. With the intention of identifying the factors that interfere with the mothers' attendance to GDF appointments, it was chosen quilombola communities in most socially vulnerable situations.

The study scenario represents the biggest concentration of black population inhabiting a municipality of Bahia, Brazil ${ }^{(9)}$. Most of the population has access to piped water supply and electric power, however, they live with the lack of basic sanitation. The main activities for family supply are fishing, catching clams, and handicraft.

In the community, there is coverage of Basic Care with the Family Health Strategy (FHS), located in the Praia Grande quilombo, the most populous one. The care is constituted by two multiprofessional teams composed by a dentist, two nurses, two doctors, two nursing technicians, an oral health technician, and seven Community Health Agents (CHA), besides the support by the Family Health Attention Center team, through a social assistant, a physical educator, physical therapist, nutritionist, psychologist, and occupational therapist.

Appointment booking in the studied Family Health Unit (FHU) is done in person, by making the professionals' (nurses and doctors) schedule available. The internal organization of this service stablishes that GDF appointments should be booked in Mondays and the appointments should occur in Thursdays. Even though the FHS advocates for the professional to act in a generalist way, one of the doctors in the investigated unit is specialized in pediatric surgeries, a situation that has oriented the mothers' preference for that professional when performing the appointments of their children.

\section{Data source}

This study has had the participation of the mothers of quilombola children younger than one year old. Initially, a door-to-door survey was performed to identify children that met the inclusion criteria: being younger than one year old and attending to GDF appointments carried out by nurses and doctors. With the intent of not skewing the study, it was chosen mothers who were the primary care-takers of the children, and who attended to follow-up appointments, as stablished by the Ministry of Health $(\mathrm{MOH})$, routinely or by spontaneous demand. Of a total of 34 identified mothers, who had children younger than one year old, 14 quilombola mothers, who lived in these communities, participated in the study.

\section{Data collection and organization}

The technique of semi-structured interviews was used, containing objective questions to characterize the women (age, race/ color, schooling level, work, marital status, income, number of children, and number of people living in the household), and the following guiding question: Which factors interfere with your attendance to the child appointments?

The interviews were performed between September 2014 and February 2015, by the PhD student of the project, and lasted for about 30 minutes. They were carried out in FHU facilities or in the children's houses, depending on the mothers' availability. The difference in collection places did not imply on behavior changes that could affect the quality of the interviews. They were performed in previously booked times, preserving the mothers' privacy and avoiding interruptions. For a better use of information, the narrations were recorded with the participants' authorization, and transcribed for further systematization and analysis. To guarantee the information's confidentiality, the interviewed women had their names identified by codenames of African women.

The data were systematized by the thematic content analysis method, using the phases of pre-analysis: material exploration; treatment; inference; and result interpretation. The discussion of the results was based on the Symbolic Interactionism Theory, once the meaning is the main concept, with individual and collective actions being constructed based on the interaction among people, who act in the social context they belong to ${ }^{(8)}$.

\section{Data analysis}

Based on the systematization process, the empirical material was grouped according to its similarities and differences, allowing for the emergence of thematic categories, namely: "Intrinsic factors" and "Extrinsic factors". Regarding the factors directly related to the mother, there are: "Meaning of the appointment for child follow-up"; "Understanding the need for the appointment in face of the child falling ill"; and "Personal issues". Extrinsic factors, which are related to the service, cover the following subcategories: "Availability of appointment booking"; "Time waiting for the appointment"; and "Appointment quality".

\section{RESULTS}

14 quilombola women participated in the study, who aged between 18 and 39 years old, with an average age of 26 years old. All of them were self-declared black women (black and brown $100 \%)$. Most of them had studied until high school, but not finished it (57.1\%); lived in a common-law marriage (57.1\%) and worked collecting clams (50\%). Moreover, $42.8 \%$ of them had only one child and $28.5 \%$ lived with other 3 or 4 people, with family incomes lower than one and a half minimum wage (at the time of the research, the value of the minimum wage was $R \$ 724.00$ ). It is highlighted that all interviewed women declared not having formal jobs, of whom 58.3\% perform low-remuneration jobs.

Different factors affect the quilombola mothers' attendance to GDF consultations, of intrinsic or extrinsic characteristics, as portrayed in the following categories:

\section{Intrinsic factors}

This category gathers the factors directly related to the interviewed mothers and that have affected their attendance to the appointments, and are organized into the following subcategories:

\section{Meaning of the appointment for child follow-up}

Quilombola mother understand that following the children's health through the GDF appointments is essential, an event that favors the attendance to the service. 
For me it is an obligation to bring the child to see how she is. Because of that, I have never missed this appointment. If I need to leave, someone takes her, because it is good to keep track. I consider it to be a duty of the mother. (Ameenah)

I keep track of her health. I take her to the nursing appointment every month, because it is normal routine. (Ashia)

\section{Understanding the need for the appointment in face of the child falling ill}

Other perceptions unveiled in the study are related to the to the mother's understanding of conditioning the appointments to the children falling ill, as it is portrayed by the following speeches:

I only bring my daughter for appointments when she is ill. (Zulai)

It needs to come to appointments when there are sick. If they are not, there is no need to come. (Zarina)

\section{Personal issues}

It is perceived that the children's attendance to appointments is affected by personal matters, especially due to the daily life demands of quilombola mothers.

I did not bring him always for the appointments because I had some personal issues, but I will start to take him again. (Zalika)

I haven't been bringing him for two months because I haven't had time. I have three children! The activities at home also prevent me from coming [...] it gets too heavy [...] I would say it is laziness actually, but I will take him. (Alika)

I had to miss the appointment because I had to solve some matters in order to receive the money from the Government. (Shany)

\section{Extrinsic factors}

This category covers the factors related to the studied FHU, which interfere with the children's attendance to GDF appointments. It is comprised by the following subcategories:

\section{Availability of appointment booking}

It is evinced that the feasibility of booking appointments affects the children's attendance to GDF appointments. This availability is conditioned to the agility in the process of booking, which makes it easier to book appointments:

[...] the process to book it does not take too long. If I come today, I can book it for the same week. (Winda)

I don't think it takes too long to book it! When I come at Monday, I can book it for Thursday in the same week. (Nikaule)

Nonetheless, some mothers complained about insufficient vacancy supply for the service, referring to long waiting periods to book appointments. Such situation may also lead to the search for care in other units:
I can't take him every month because there is no spot. There are 25 attendance forms each day. We can take two or three months to be able to book the appointment. (Adwin)

In relation to booking, it takes too long, the waiting time is crushing. The service could be better, better organized [...] because of that, I prefer looking for another unit. (Leiza)

\section{Time waiting for the appointment}

The study shows that the time waiting for the appointment is affected by the high number of children looking for this service, as well as by the professionals' behavior, who are not assiduous and on time. Such event negatively affects the mothers' daily lives:

It takes too long to call us because it is a lot of people. We arrive early, but it is no use. [...] what happens is that they [the professionals] go lunch and take too long to come back. [...] the worst is when we book it and, on the day, the doctor doesn't come. I wake up early to cook and, when I get there, there is no doctor! (Faizah)

[...] if I could change something, it would be the time waiting. Here, it works according to "first come, first served": if we get here early, the line is smaller; if we arrive a little later, the line is long! Besides, the professionals arrive late and, when they go to their breaks, they take too long to come back. (lori)

\section{Appointment quality}

The factors related to appointment quality mentioned by the quilombola mothers concern the behavior of the health professional and, at the same time, to the time made available to care for the children. Considering that, in the studied unit, the GDF appointments are the doctors' responsibility, the speeches were directed to critiques to this professional.

The service is too bad. [...] it is an unkind person, who is not patient with children. Everybody complains! (Faizah)

If there was more than one doctor, it would be better, because it could increase the time in the appointment. (Zaila)

\section{DISCUSSION}

The study allowed for understanding that the attendance of quilombola children to growth and development follow-up appointments is affected by intrinsic factors, belonging to the mothers, and extrinsic ones, related to the health service. Regarding intrinsic factors, quilombola mothers evinced personal issues that are sometimes prioritized over the need for keeping track of the child's health, for example, domestic activities. Such demands are influenced by the cultural context, which considers home chores as the main function of women. Thus, the studied mothers understand they need to first fulfill the daily domestic demands. In agreement to these data, a study performed in São Paulo, Brazil, indicated that women end up spending more time with house maintenance and feeding functions ${ }^{(20)}$

The decision of meeting domestic demands over the follow-up of the child's health can be explained by the SI, once the interactions 
stablished by these mothers with the environment they live in can contribute for the behavior of (not) looking for GDF appointments. In the studied context, it is based on the mothers' interactions and social gender stereotypes that domestic obligations are designated to women. In this sense, taking care of home as a attribute inherent to women is constituted a symbol built in the interaction among subjects. This reality is even more difficult to be deconstructed when dealing with black women, since, when compared to white ones, they face more difficulties in finding formal jobs ${ }^{(21)}$.

Also connected to intrinsic factors is the fact that quilombola mothers understand that looking for GDF services is conditioned to the presence of illnesses, a factor that also hampers the children's attendance to this service. This behavior can be based on the technocratic/biomedical model, which understands health as the lack of disease ${ }^{(22)}$. This paradigm sets a sporadic and curative assistance, centered around biological aspects ${ }^{(23)}$, which ends up devaluing other elements affecting this process, as the life habits of this population.

In the case of quilombola children, it must be considered that this scenario may be related to the distance of this population's culture, who, by interacting with different social symbolic contexts, apprehends new ways of taking care of their children and dealing with sickness, devaluing the traditional alternatives of African-descendent culture, such as the use of teas and herbs, ointments, massages, baths, spiritual support, among others. Even tough these practices are not highlighted in this study, using the resources of the African-descendent culture itself is still valued by African mothers belonging to rural communities ${ }^{(24)}$.

A study performed in a community of remaining quilombolas in Morro do Chapéu, Bahia, Brazil, has evinced that, in face of a lacking public health system, these communities' beliefs in vegetal resources is an alternative for treating the most common diseases in the group. Besides, this knowledge can be identified in other African-origin communities, as in Candomblé temples ${ }^{(25)}$. In this communities, there seems to be a coexistence between conventional drug therapy and the traditional therapies in a harmonious way.

It is highlighted that health professionals, specially nurses, given their leading role in the care for children in the FHS, understanding the particularities of quilombola communities, should respect and value other health promotion methods common to them. Based on this valuation, and connected to the implementation of integrative and complementary practices, as well as qualified listening, it is possible to foment the mothers' autonomy and leading role, stablishing an attentive and respectful dialogue between professional and client, thus favoring the design of diagnoses and treatments in accordance to their needs. This process allows for the empowerment of the user, leading to a conscious co-responsibility and co-participation in the therapeutic plan. These prerogatives widen concept bases about health care beyond allopathy and biomedical rationality, including, in this process, complementary practices, social and subjective dimensions, interdisciplinary action, exchange between subjects, creation of bonds and trust, which are valued by the concept of Expanded Clinic, instituted by the National Policy of Care and Administration Humanization (HumanizaSUS) since 2004(26). Based on this interaction, the creation of professional-client bonds is emphasized, which can enable the family adhesion to GDF appointments and the continuity of assistance.
These elements, despite not being highlighted in this research, can also positively affect children's attendance to GDF appointments. This happens when mothers change their perception on the health-illness process and, based on the interaction with the community they live in, it makes them confer a favorable meaning to the service, thus understanding its need. This idea can be based on the individuals' interaction with themselves, being regulated by what is socially constructed among subjects. Concerning that, a Colombian study signals that the full participation of parents and family in child care implies on sensitizing them in relations to the importance of performing health follow-up. This study also draws the attention to the essential communication and guidance of the family ${ }^{(27)}$, recognizing their relevance for the care and raising of their children.

However, by valuing the health service follow-up and, thus, looking for it, women face difficulties regarding appointment booking. It is observed that, when the access is made difficult, appointments become less frequent. In this sense, when accessibility is crossed by an insufficient number of spots, it leads to long waiting lines, making it harder to perform periodical follow-ups for quilombola children, an evidence also observed in a study with a similar population ${ }^{(28)}$.

A research carried out in Belo Horizonte, Minas Gerais, Brazil, with a sample of 7.778 individuals confirms the occurrence of long lines in the collective health services as one of the main obstacles for assistance ${ }^{(29)}$. It must be considered that waiting lines may also be related to the tendency for booking appointments and/or preference for GDF appointments performed by a doctor, which overwhelms these professionals by prioritizing them over nurses. Another research was already pointing out that bookings are hard to make due to the number of people, which is worsened when there is insufficient availability of professionals in this area ${ }^{(30)}$.

This reality goes against the National Basic Care Policy (PNAB), which stablishes how the FHS works, and stablishes that family follow-up must be performed in a shared manner based on a multi-professional aspect, having the teams minimally composed by a generalist doctor, or one who is specialized in Family Health, or Family and Community doctor; a generalist nurse, or one who specialized in Family Health; a nursing technician or assistant; and community health agents; being possible to also have the following oral health professionals: generalist dental surgeon, or one who is specialized in Family Health; and an oral health technician and/or assistant ${ }^{(8)}$. Besides this policy, there is also the legal support of the Brazilian Federal Nursing Council (COFEN), which sets the nursing appointment as a private nurse activity, as mentioned in the Law no. 7.498 of June $25^{\text {th }}, 1986$, published in the Union Official Journal in $06 / 26 / 1986$ and regulated by the Decree no. 94.806, art. 11 ${ }^{(31)}$. However, given that, in one of the health units, the doctor is a professional specialized in pediatrics, this context compromises the leading role of the generalist or family nurse on collective health, once it influences mothers to choose for the doctor. Nonetheless, it is important to highlight the importance of the assistance given by the nurse in the FHS and in other units of the Basic Care network, since it is currently related to the reduction of child morbimortality rates ${ }^{(32)}$.

Another factor compromising the attendance of this public is the low availability of appointments, when related to the high 
demand of children to be consulted. A national and international study, carried out in the district of Thekwini, in South Africa, reveals that the low offer of appointments combined with the overload of consultations increase the demands for the unit's team, as well as the waiting time, and favors the dissatisfaction with the service $^{(29,33)}$. This increased waiting time, as pointed out by the mothers in our study, can even contribute to abandoning the treatment. It is important to highlight that work overload for the professionals affects user assistance negatively, as observed by a research performed with health professionals in the municipality of Acarati, Ceará, Brazil ${ }^{(34)}$.

Regardless of the interferences on the access of quilombola mothers to the service, their attendance is influenced by other elements that compromise its quality. In this perspective, they mention the professionals' presence and timeliness, be it due to delays in beginning the activities in the unit or due to absences in the service. A quantitative study carried out with 400 hypertension patients in Fortaleza, Ceará, Brazil, identifies the professionals' timeliness as one of the criteria that favor treatment adhesion ${ }^{(35)}$. Despite not being part of this research's results, not complying to the daily workhours in basic care may be connected to the possible existence of other employment bonds, especially for doctors and dentists ${ }^{(36)}$. This situation reminds us of values and ethical conducts about the working processes, still not covered be their respective professional ethic $\operatorname{codes}^{(37)}$.

Besides pre-appointment factors that interfere with attendance, mothers also complained of the short assistance during the appointment, and of an inadequate professional posture, events that make the interaction between mother and health professional harder. This could be also observed by a qualitative study, performed with users of six Basic Health Units (UBS) in two sanitary districts of São Paulo, Brazil, which identified, among the complaints, the quick medical assistance, creating no bonds or being indelicate ${ }^{(38)}$. Also, in a study performed with nurses of health units in Paraíba, Brazil, identified that it is common to observe lack of interaction relations, and co-participation and production of subjectivity among mothers and the nurse during GDF appointments, a situation that may favor treatment abandonment ${ }^{(39)}$.

This scenario allows for discussion on the need for humanizing the assistance in health services that has based the HumanizaSUS Policy, which has as its principles the attentive and ethically engaged listening, as well as being interested in recognizing the other ${ }^{(26)}$. Thus, it aims at having the professional to take on an attentive behavior, which will contribute to the interaction between professionals and mothers and, thus, result on a relationship based on care, trust, and on attendance to GDF appointments.

\section{Study limitations}

The work points out as study limitations the organizational dynamics of the studied FHS, since it guides the appointments to the doctor, compromising the follow-up performed by nurses. The fact that the doctor was specialized in pediatrics may have affect the search for growth and development follow-up performed by him and, consequently, the higher attendance. Another aspect that should be mentioned is the size of the population studied, composed by 14 mothers, since they do not represent the total number of quilombola mothers of children younger than one year old, which is of 32 women.

\section{Contributions to Nursing}

The scientific evidences unveiled in this study allow for guiding the nursing area towards a administration of the health unit that may enable bookings aimed at reducing the waiting time, also taking into account the personal issues that make it harder for mothers to access the service. Regarding these issues, in the sense of favoring the adhesion to appointments, such professionals, along with the others in the FHS, can prioritize the care for quilombola children and develop, along with mothers, health education actions focused on the importance of this follow-up in the public health scenario. These actions may allow for a welcoming assistance, contributing for the attendance of quilombola mothers to the appointments and, consequently, for the collective health of children.

Besides, it is believed that the increase/enhancement of the quality of health basic care is an effective strategy for the search of better health promotion, disease prevention, with the potential to improve people's health state, reflecting on the improvement of health indicators. Within this context, a work of nurses becomes essential by contributing to the health condition of the populations they care for. Family health teams that are properly qualified and committed to collective health can develop an essential role in facing the inequities of marginalized populations, which includes quilombola communities.

\section{FINAL CONSIDERATIONS}

The study has pointed out intrinsic and extrinsic factors related to the attendance of quilombola children to GDF appointments. Regarding those intimately related to the mothers, the adhesion suffers the influence of the meaning the give to the follow-up, of the connection between the appointments and illness situations, besides personal matters, specially related to daily domestic demands.

The factors related to the service involve the availability for bookings, the time waiting for the appointments and their quality, expressed by the health professional's posture and by the time made available for caring for the children. Analyzing them by the Symbolic Interactionism perspective, these factors are caused by the symbolic communication that quilombola mothers apprehend based on their interaction with the community and the professionals acting on the health service.

The search for the service may be encouraged by the stimulating the interaction between mothers and professionals, through the humanization of care, of qualified listening, and educational actions that may transform the perception of the mothers on the importance of the appointments. Likewise, it is demanded that the administration be organized to offer the services, for the process of booking the appointments, and for the reduction of the time waiting at the reception, factors that contribute to increase the quality of the appointment in the scenario of collective health and to improve the attendance of quilombola mothers.

Considering the factors found in this research, it is also necessary to encourage the participation of other family members, specially 
Factors related to quilombola attendance to child follow-up appointments Oliveira EF, Camargo CL, Gomes NP, Couto TM, Campos LM, Oliveira PS.

fathers, in GDF appointments, so that the responsibility for taking care of the children is not only given to mothers. Moreover, it is indispensable to promote actions valuing traditional quilombola practices related to the promotion of health, and healthy child growth and development through guidance in the community and in the health service.

\section{FUNDING}

National Council of Science and Technology (CNPq; funded public notice); Research Support Foundation in the State of Bahia (FAPESB; funded public notice) and coordination for higher educational improvement (CAPES; PhD scholarship).

\section{REFERENCES}

1. Andrade DA, Lacerda RS, Silva TC, Voci SM. Avaliação da situação de insegurança alimentar em uma comunidade quilombola de Sergipe. Segur Aliment Nutr. 2017;24(2):125-40. doi: 10.20396/san.v24i2.8650336

2. Denno DM, Paul SL.C hild health and survival in a changing world. Pediatr Clin North Am. 2017;64(4):735-54. doi: 10.1016/j.pcl.2017.03.013

3. Staines A, Balanda KP, Barron S, Corcoran Y, Fahy L, Gallagher L, et al. Child health care in Ireland. J Pediatr. 2016;177S:S87-106. doi: 10.1016/j. jpeds.2016.04.046

4. Prenkert M, Ehnfors M. Growth data of underprivileged children living in rural areas of Chin State, Burma/Myanmar, compared to the WHO reference growth standards: an observational study. BMJ Open. 2016;6:e009119. doi: 10.1136/bmjopen-2015-009119

5. Tlou B, Sartorius B, Tanser F. Spatial-temporal dynamics and structural determinants of child and maternal mortality in a rural, high HIV burdened South African population, 2000-2014: a study protocol. BMJ Open. 2016;6:e010013. doi: 10.1136/bmjopen-2015-010013

6. Kochergin CN, Proietti FA, César CC. Comunidades quilombolas de Vitória da Conquista, Bahia, Brasil: autoavaliação de saúde e fatores associados. Cad Saúde Pública. 2014;30(7):1487-501. doi: 10.1590/0102-311X00141213

7. Carvalho EB, Sarinho SW. The nursing consultation in monitoring child growth and development in the family health strategy. Rev Enferm UFPE. 2016;10 (Suppl. 6):4804-12. doi: 10.5205/1981-8963-v10i6a11259p4804-4812-2016

8. Ministério da Saúde (BR). Secretaria de Atenção à Saúde. Departamento de Atenção Básica. Saúde da criança: crescimento e desenvolvimento [Internet]. Brasília: Ministério da Saúde; 2012 [cited 2018 Jan 8]. (Cadernos de Atenção Básica n 33). Available from: http://189.28.128.100/dab/docs/publicacoes/cadernos_ab/caderno_33.pdf

9. Presidência da República (BR). Lei no 13.257, de 8 de março de 2016. Dispõe sobre as políticas públicas para a primeira infância e altera a Lei n 8.069, de 13 de julho de 1990 (Estatuto da Criança e do Adolescente), o Decreto-Lei n 3.689, de 3 de outubro de 1941 (Código de Processo Penal), a Consolidação das Leis do Trabalho (CLT), aprovada pelo Decreto-Lei n 5.452, de $1^{\circ}$ de maio de 1943, a Lei n 11.770 , de 9 de setembro de 2008, e a Lei no 12.662, de 5 de junho de 2012 [Internet]. Diário Oficial da União, Brasília, 9 mar. 2016 [cited 2018 Jan 8 ]. Available from: http://www.planalto.gov.br/ccivil_03/_Ato2015-2018/2016/Lei/L13257.htm

10. Vieira VCL, Fernandes CA, Demitto MO, Bercini LO, Scochi MJ, Marcon SS. Puericultura na atenção primária à saúde: atuação do enfermeiro. Cogitare Enferm. 2012;17(1):119-25. doi: 10.5380/ce.v17i1.26384

11. Campos RMC, Ribeiro CA, Silva CV, Saparolli ECL. Nursing consultation in child care: the experience of nurses in the Family Health Strategy. Rev Esc Enferm USP. 2011;45(3):565-73. doi: 10.1590/S0080-62342011000300003

12. Almeida AC, Mendes LC, Sad IR, Ramos EG, Fonseca VM, Peixoto MVM. Use of a monitoring tool for growth and development in Brazilian children: systematic literature review. Rev Paul Pediatr. 2016;34(1):122-31. doi: 10.1016/j.rpped.2015.06.012

13. United Nations (UN). Millennium Development Goals Indicators. MDG Country Progress Snapshot: Brazil [Internet]. New York: UN; 2015 [cited 2019 Mar 27]. Available from: http://mdgs.un.org/unsd/mdg/Resources/Static/Products/Progress2015/Snapshots/BRA.pdf

14. Vitolo MR, Gama CM, Campagnolo PDB. Frequência de utilização do serviço público de puericultura e fatores associados. J Pediatr. 2010;86(1):80-4. doi: 10.2223/JPED.1966

15. Cunha CLF, Silva RA, Gama MEA, Costa GRC, Costa ASV, Tonial SR. O uso de serviços de atenção primária à saúde pela população infantil em um estado do nordeste brasileiro. Cad Saúde Pública. 2013;21(2):115-20. doi: 10.1590/S1414-462X2013000200003

16. Ximenes Neto FRG, Queiroz CA, Rocha J, Cunha ICKO. Por que eu não levo meu filho para a consulta de puericultura... Rev Soc Bras Enferm Ped [Internet]. 2010 [cited 2018 Jan 8];10(2):51-9. Available from: https://sobep.org.br/revista/images/stories/pdf-revista/vol10-n2/v.10_n.2art1.pesq-por-que-nao-levo-meu-filho-para-consulta.pdf

17. United Nations Children's Fund (UNICEF). Situação atual da infância. Caderno Brasil. New York: UNICEF; 2008.

18. Baltor MRR, Rodrigues JSM, Moura KR, Borges AA, Dupas G, Wernet M. Autonomia da familia e a relação com os profissionais de saúde. Ciênc Cuid Saúde. 2012;11(1):44-50. doi: 10.4025/cienccuidsaude.v11i1.18857

19. Instituto Brasileiro de Geografia e Estatística (IBGE). Síntese de Indicadores Sociais: uma análise das condições de vida da população brasileira [Internet]. Rio de Janeiro: IBGE; 2013 [cited 2016 Aug 21]. Available from: http://biblioteca.ibge.gov.br/visualizacao/livros/liv66777.pdf

20. Santos EF, Diogo MF, Schucman LV. Entre o não lugar e o protagonismo: articulaçoes teóricas entre trabalho, gênero e raça. Cad Psicol Soc Trab. 2014;17(1):17-32. doi: 10.11606/issn.1981-.0490.v17n1p17-32

21. Collins PH. Aprendendo com a outsider within: a significação sociológica do pensamento feminista negro. Soc Estado. 2016;31(1):99-127. 
Factors related to quilombola attendance to child follow-up appointments Oliveira EF, Camargo CL, Gomes NP, Couto TM, Campos LM, Oliveira PS.

doi: 10.1590/S0102-69922016000100006

22. Baeta SMF. Cultura y modelo biomédico: reflexiones en el proceso de salud-enfermedad. Comunidad Salud [Internet]. 2015 [cited 2016 Aug 20];13(2):81-3. Available from: http://ve.scielo.org/scielo.php?script=sci_arttext\&pid=S1690-32932015000200011

23. Marques AS, Freitas DA, Leão CDA, Oliveira SKM, Pereira MM, Caldeira AP. Atenção Primária e saúde materno-infantil: a percepção de cuidadores em uma comunidade rural quilombola. Ciênc Saúde Colet. 2014;19(2):365-71. doi: 10.1590/1413-81232014192.02992013

24. Østergaard LR, Bjertrup PJ, Samuelsen H. “Children get sick all the time”: a qualitative study of socio-cultural and health system factors contributing to recurrent child illnesses in rural Burkina Faso. BMC Public Health. 2016;16:384. doi: 10.1186/s12889-016-3067-0

25. Silva NCB, Regis ACD, Esquibel MA, Santos JES, Almeida MZ. Uso de plantas medicinais na comunidade quilombola da Barra II - Bahia, Brasil. Bol Latinoam Caribe Plantas Med Aromát [Internet]. 2012 [cited 2016 Aug 23];11(5):435-53. Available from: http://www.redalyc.org/articulo. oa?id=85624131006

26. Schveitzer MC, Esper MV, Silva MJP. Integrative and complementary therapies in primary health care: a way to humanize care. Mundo Saúde [Internet]. 2012 [cited 2018 Jan 16];36(3):442-51. Available from: http://www.revistamundodasaude.com.br/assets/artigos/2012/95/6.pdf

27. Hernández NL, Rubio-Grillo MH, Lovera A. Strategies for neonatal developmental care and family-centered neonatal care. Invest Educ Enferm. 2016;34(1):104-12. doi: 10.17533/udea.iee.v34n1a12

28. Trad LAB, Castellanos MEP, Guimarães MCS. Accessibility to primary health care by black families in a poor neighborhood of Salvador, Northeastern Brazil. Rev Saúde Pública. 2012;46(6):1007-13. doi: 10.1590/S0034-89102012000600010

29. Lima-Costa MF, Turci MA, Macinko J. A comparison of the Family Health Strategy to other sources of healthcare: utilization and quality of health services in Belo Horizonte, Minas Gerais State, Brazil. Cad Saúde Pública. 2013;29(7):1370-80. doi: 10.1590/ S0102-311X2013000700011

30. Sousa FOS, Medeiros KR, Gurgel Jr GD, Albuquerque PC. Do normativo à realidade do Sistema Único de Saúde: revelando barreiras de acesso na rede de cuidados assistenciais. Ciênc Saúde Colet. 2014;19(4):1283-93. doi: 10.1590/1413-81232014194.01702013

31. Presidência da República (BR). Lei n 7.498, de 25 de junho de 1986. Dispõe sobre a regulamentação do exercício da enfermagem, e dá outras providências [Internet]. Diário Oficial da União, Brasília, 26 jun. 1986 [cited 2018 Feb 21]. Avaliable from: http://www.planalto.gov.br/ ccivil_03/Leis/L7498.htm

32. Baratieri T, Soares LG, Botti ML, Campanini AC. Nurse consultation in child care: a focus on medical records. Rev Enferm UFSM. 2014;4(1):20616. doi: $10.5902 / 217976928553$

33. Sokhela DG, Makhanya NJ, Sibiya NM, Nokes KM. Experiences of Fast Queue health care users in primary health care facilities in eThekwini district, South Africa. Curationis. 2013;36(1):E1-8. doi: 10.4102/curationis.v36i1.60

34. Soares DG, Pinheiro MCX, Queiroz DM, Soares DG. Implementation of childcare and care challenges in the Family Health Strategy in a city of the Ceará state. Rev Bra Promoç Saúde. 2016;29(1):132-8. doi: 10.5020/18061230.2016.p132

35. Santos ZMSA, Marques ACT, Carvalho YP. Factors associated to treatment adherence in hypertensive users. Rev Bras Promoç Saúde. 2013;26(2):298-306. doi:10.5020/18061230.2013.p298

36. Sato M, Ayres JRCM. Art and humanization of health practices in a primary care unit. Interface (Botucatu). 2015;19(55):1027-38. doi: 10.1590/1807-57622014.0408

37. Nunes EFPA, Santini SML, Carvalho BG, Cordoni Jr L. Força de trabalho em saúde na Atenção Básica em Municípios de Pequeno Porte do Paraná. Saúde Debate. 2015;39(104):29-41. doi: 10.1590/0103-110420151040174

38. Trombetta AP, Ramos FRS, Vargas MAO, Marques AMB. Singularities work of a rehabilitation center under the perspective of the healthcare team. Esc Anna Nery. 2015;19(3):446-53. doi: 10.5935/1414-8145.20150059

39. Assis WD, Collet N, Reichert APS, Sá LD. Processo de trabalho da enfermeira que atua em puericultura nas unidades de saúde da família. Rev Bras Enferm. 2011;64(1):38-46. doi: 10.1590/S0034-71672011000100006 